\title{
Factors affecting willingness to communicate in a Spanish university context
}

\author{
ANA CRISTINA LAHUERTA* \\ Universidad de Oviedo
}

Received: 01/03/2014. Accepted: 03/08/2014.

\begin{abstract}
The present study examines the relationships among the variables believed to affect Spanish undergraduates' willingness to communicate in English. The participants were 195 students majoring in several degrees at the University of Oviedo. A questionnaire and a standardized English Test were administered to the students in February-March 2013. Regression analysis showed that the Spanish undergraduates' motivation to learn English had a significant relationship with their willingness to communicate in English. Results also showed a significant positive relationship between self-perceived communication competence and willingness to communicate, and a significant negative relationship between anxiety and self-perceived communication competence. Finally, results show a significant relationship between self-perceived communication competence and L2 competence. A gender difference in the effect of self-perceived competence on actual L2 competence was another finding of the present study.
\end{abstract}

KEYWORDS: willingness to communicate, self- perceived communication competence, anxiety, L2 competence, motivation.

\section{RESUMEN}

Este artículo examina la relación entre las variables que pueden afectar el deseo de comunicarse en inglés por parte de estudiantes de esta lengua. Los participantes son estudiantes universitarios de distintos grados de la Universidad de Oviedo. Se administraron un cuestionario elaborado para el estudio así como un test de inglés a los estudiantes entre febrero y marzo de 2013. El análisis de regresión muestra que la motivación de los estudiantes para aprender inglés está relacionada significativamente con su deseo de comunicarse en esa lengua. Descubrimos también que la competencia comunicativa auto percibida está relacionada de manera positiva con el deseo de comunicarse en inglés y de manera negativa con la ansiedad. Se observa además una relación significativa entre la competencia comunicativa auto-percibida y la competencia real en la lengua así como una diferencia de género en esta relación.

PALABRAS ClAVE: Deseo de comunicarse, competencia auto-percibida, ansiedad, competencia real, motivación.

*Address for correspondence: Ana Cristina Lahuerta. Departamento de Filología Anglogermánica y Francesa, Universidad de Oviedo, Spain. E-mail: lahuerta@uniovi.es 


\section{INTRODUCTION}

Communicative competence in the target language is the final objective of language learning. According to Dörnyei (2007:45), the difference between seeking to communicate in the target language and avoiding such communication is because of "psychological, linguistic, and contextual variables." Willingness to communicate (WTC), the construct that was first proposed by McCroskey and Baer (1985), is concerned with these variables. It refers to the tendency of an individual to initiate communication when free to do so.

As the emphasis in L2 teaching and learning has been shifting to communication, studies are needed that approach students' attitudes to communication in a second (L2) language in different contexts. The present study examines the relationships among the variables believed to affect Spanish undergraduates' willingness to communicate in English. The current study is aimed at contributing to the examination and testing of the L2 WTC construct, thus continuing the line of research initiated in the 1990s, in an attempt to enrich the theoretical foundation of this construct in a different country and linguistic environment. Although the concept willingness to communicate could include communication in written forms (MacIntyre et al. 1998), this study focuses exclusively on oral communication or, more specifically, talking in a L2.

\section{THEORETICAL FRAMEWORK}

WTC originally referred to communication in the first or native language (L1) (McCroskey, 1992). It reflects the stable predisposition to talk in various situations and it is seen essentially as a personality trait (MacIntyre et al., 1998). However, WTC is different when seen in a L2 context. MacIntyre et al. (1998) do not consider WTC in the second language L2 as a simple manifestation of WTC in the first or native language L1 because a much greater range of communicative competence is evident in a L2 than in a L1. In addition, "L2 carries a number of intergroup issues, with social and political implications, that are usually irrelevant to L1 use" (MacIntyre et al., 1998). The issue of whether WTC is a permanent trait or is modified by the situational context has been investigated in various studies (e.g. Cao \& Philp, 2006; Kang, 2005; MacIntyre \& Legatto, 2011) with mixed results.

MacIntyre et al. (1998) present a heuristic model that shows the range of potential influences on WTC in the L2. The interrelations among the constructs are presented in a pyramid-shaped structure. As these authors explain, the pyramid shape shows the immediacy of some factors and the relatively distal influence of others. The model includes six categories referred to as layers: the first three layers represent situation-specific influences on WTC at a given moment in time; the other three layers represent stable, enduring influences on the process. 
The two variables that appear to be key in WTC (which most directly influence WTC) are perceived competence and anxiety. Communicative competence is defined as "adequate ability to pass along or give information; the ability to make known by talking or writing" (McCroskey \& McCroskey, 1988: 109). On the other hand, the term perceived communication competence refers to how an individual believes his/her communication competence is, based on self-awareness rather than the actual communication competence (McCroskey \& McCroskey, 1988). Baker and MacIntyre (2000) argue that it is not the individual actual skill that counts, rather it is how he/she perceives their communication competence that will determine WTC.

The research of McCroskey and McCroskey (1986) found a strong correlation between perceived communicative competence and WTC. Similarly, a positive relationship between perceived communicative competence and WTC was also found in the study carried out by Matsuoka (2005) with a group of Japanese university students. Cameron (2013) reports on a study in a New Zealand university with participants who were permanent migrants from Iran. These students completed a questionnaire and participated in further in-depth semi-structured interviews. This author identifies six factors as having an effect on students' WTC: selfperceived communicative competence, personality, anxiety, motivation and the importance of English, and the learning context.

Yousef et al. (2013) obtain similar results. These authors investigate Malaysians' willingness to communicate in English as a second language. The results showed that selfperceived communication competence affected WTC. Further, the results also demonstrate that motivation influenced WTC indirectly through the two variables self-perceived communication competence and communication apprehension.

The other major variable found to predict willingness to communicate is anxiety or communication apprehension (MacIntyre \& Charos, 1996). This variable refers to "an individual's level of fear or anxiety associated with either real or anticipated communication with another person or persons" (McCroskey, 1997: 192). McCroskey and McCroskey (1986) found a significant negative correlation between communication apprehension and WTC. Thus, the greater the anxiety, the less likely the person will be willing to communicate. Some other studies have shown that there is a negative relationship between L2 WTC and anxiety (Gardner \& MacIntyre, 1993; MacIntyre \& Clément, 1996). In other words, anxious students are reluctant to express themselves verbally in L2 conversations.

MacIntyre (1994) developed a path model that postulates that WTC involves a combination of greater perceived communicative competence and a lower level of communication anxiety. He applied this model to L2 communication and showed that anxiety about L2 communication and perceived L2 communicative competence consistently predicted WTC in L2.

In a similar way, MacIntyre and Charos (1996) and MacIntyre and Clément (1996) examined the relationship among variables underlying WTC in a L2. In these studies, anxiety 
about L2 communication and perceived L2 communicative competence predicted L2 WTC. Moreover, motivation was a predictor of WTC, frequency of communications in a L2 or both.

Yashima (2002) obtains similar results. This author carried out a study with a sample of Japanese university students. She found that a lower level of anxiety and higher selfperceived communication competence led to a higher level of WTC. This resulted in higher proficiency. Moreover, she also found that motivation affected WTC.

In a later study, Yashima et al. (2004) carry out two separate investigations conducted with Japanese adolescent learners of English. In the first investigation, they found that WTC and self-perceived communication competence results in more frequent communication in the L2, which leads to higher L2 competence, and that motivation affects WTC and communication behaviour. The second investigation with students who participated in a study-abroad program in the United States confirmed the results of the first.

Croucher (2013) examined communication apprehension, self-perceived communication competence, and WTC. The participants were college students at the University of Jyvaskyla, Finland. Results revealed that communication apprehension was negatively correlated with self-perceived communication competence, and willingness to communicate, whereas willingness to communicate and self-perceived communication competence, were positively correlated.

Baker and Macintyre (2000) include other variables like gender in their analysis of communication. They examined the effects of an immersion versus a non-immersion program on perceived competence, WTC, self-reported frequency of communication, communication anxiety, and motivation of students who had English as their L1 and were studying French as their L2. The results of correlations among the communication variables were different for groups with or without immersion experiences. Communication anxiety/apprehension significantly correlated with WTC in French for both groups. However, perceived competence in French did not significantly correlate with WTC in French for the immersion group, but had a strong correlation with WTC for the non-immersion group. Regarding gender, male non-immersion students showed the least positive attitudes toward learning French. The study also revealed male immersion students' highest job-related orientations and female non-immersion students' highest travel, knowledge, and personal achievement orientations. The authors attributed this difference in reasons for learning a language to females' social orientation as well as the increased experience of the immersion group.

In sum, the studies reviewed demonstrate that both self-perceived communicative competence and motivation influence WTC. They also show a negative correlation between self-perceived communication competence and anxiety as well as between WTC and anxiety. Baker and MacIntyre's (2000) fairly inconclusive result with respect to gender calls for further research. The importance of the relationships between WTC, motivation and selfperceived competence in L2 teaching and learning and the lack of studies that approach them in a Spanish higher education context led us to carry out an empirical study that focusses on 
the relationships among the variables believed to affect Spanish L1 speakers' willingness to communicate in English.

\section{HYPOTHESES OF THE STUDY}

Considering the previous research studies examined, we tested the following hypotheses:

Hypothesis 1: The greater the students' level of motivation the greater their willingness to communicate.

Hypothesis 2: The greater the students' self-perceived communicative competence the greater their willingness to communicate.

Hypothesis 3: The lower the students' anxiety the greater their self-perceived communication competence.

We decided to add a further hypothesis based on the relationship between selfperceived communication competence and L2 competence, which was formulated as follows:

Hypothesis 4: The greater the students' self-perceived communication competence the greater their L2 competence.

\section{PARTICIPANTS}

The participants were 195 students majoring in Chemistry, Geography, Musicology, Art History, Finance and Accountancy, Tourism, Computing, and Industrial Engineering at the University of Oviedo. They all had English for Specific Purposes as a subject in their curriculum. They were all Spanish L1 speakers. None of these subjects had additional exposure to the English language, apart from the usual channels of music, TV and Internet. The table below shows the distribution of students by major.

\begin{tabular}{|l|c|}
\hline DEGREE & NUMBER OF PARTICIPANTS \\
\hline CHEMISTRY & 48 \\
\hline GEOGRAPHY & 28 \\
\hline MUSICOLOGY & 18 \\
\hline ART HISTORY & 8 \\
\hline FINANCE AND ACCOUNTANCY & 8 \\
\hline TOURISM & 44 \\
\hline COMPUTING & 15 \\
\hline INDUSTRIAL ENGINEERING & 26 \\
\hline TOTAL & $\mathbf{1 9 5}$ \\
\hline
\end{tabular}

Table 1. Distribution of students by major 


\section{MATERIALS AND METHODS}

A questionnaire and a standardized English Test were administered to the students in February-March 2013. The standardized English Test was administered prior to completing the questionnaire. This test consisted of a total of 200 items including listening comprehension, grammar and Use of English items.

Regarding the questionnaire, a description of the scales follows. We changed the original format of the scales to a 5-point scale.

1) Willingness to communicate in English. This study used the WTC scale published in McCroskey (1992). The scale has 20 items (related to four communication contexts, i.e., public speaking, talking in meetings, talking in small groups, and talking in dyads; and three types of receivers: strangers, acquaintances, and friends).

2) Communication Anxiety in English. The twelve items for communication apprehension or anxiety used by MacIntyre and Clément (1996) served as the measure of communication anxiety in English. The students indicated the percentage of time they would feel nervous in each situation/receiver. The items applied to the same four communication contexts and the three types of receivers in the WTC scale.

3) Self-perceived Communication Competence in English. Twelve items, from MacIntyre and Charos (1996), constituted the measure of self-judgment of communication competence. Students indicated their self-assessed competency in each situation and with each receiver. The contexts and receivers are the same as the ones for the WTC and Communication Anxiety Scale.

4) Motivation was assessed with the Motivational Intensity, Desire to Learn the Language and Attitude toward Learning the language scales of the Attitude/Motivation Test Battery (AMTB) (Gardner 1985; Gardner and Lambert 1972):

5) Motivational intensity. As a measure of motivation, we used six items on Motivational intensity taken from Gardner and Lambert (1972).

6) Attitudes toward Learning English. As a measure of motivation, four items on Attitudes towards Learning English were taken from Gardner (1985).

7) Desire to Learn English. The other measure of motivation consisted of five items defined under the rubric Desire to Learn English from Gardner (1985). 


\section{RESULTS OF THE FACTOR ANALYSIS}

What follows is an explanation of the results of the factor analysis undertaken. In parenthesis appear the factor loadings of each item.

Factor 1 obtained significant loadings from eight items (Cronbach's alpha $=0.944)$ : Talk with a friend while standing in line (0.859); Talk with an acquaintance while standing in line (0.838); Talk in a large meeting of friends (0.856); Talk in a large meeting of acquaintances $(0.885)$; Talk in a small group of acquaintances $(0.880)$; Talk with a spouse (or girl/boyfriend) (0.780); Present a talk to a group of acquaintances 80.728); Talk in a small group of friends (0.911). This factor is labelled Willingness to communicate/talk with friends and acquaintances.

Factor 2 obtained significant loadings from eight items (Cronbach's alpha $=0.934)$ : Talk with a stranger while standing in line (0.804); Talk with a secretary (0.898); Talk with a salesperson in a store (0.888); Talk with a police officer (0.799); Talk with a waiter/waitress in a restaurant $(0.828)$; Talk with a garbage collector $(0.779)$; Talk with a service station attendant (0.848); Talk with a physician (0.755). This factor is labelled Willingness to communicate/talk in dyads with a stranger.

Factor 3 obtained significant loadings from four items (Cronbachs' alpha $=0.934$ ): Talk in a small group of strangers (0.769); Talk in a large meeting of strangers (0.855); Present a talk to a group of strangers (0.817). Present a talk to a group of friends (0.869). This factor is labelled Willingness to communicate public speaking and talk with strangers.

Factor 4 obtained significant loadings from eight items (Cronbach's alpha $=0.953$ ): Talk with an acquaintance (0.840); Talk in a large meeting of friends (0.898); Talk with a friend (0.822); Talk in a large meeting of acquaintances (0.917); Present a talk to a group of friends (0.814); Talk in a small group of acquaintances (0.902); Talk in a small group of friends (0.888); Present a talk to a group of acquaintances $(0.866)$. This factor is labelled SelfPerceived communication competence public speaking and talk with friends and acquaintances.

Factor 5 obtained significant loadings from four items (Cronbach's alpha $=0.886$ ): Present a talk to a group of strangers (0.804); Talk in a small group of strangers (0.887); Talk with a stranger (0.855); Talk in a large meeting of strangers (0.905). This factor is labelled Self-Perceived communication competence public speaking and talk with strangers.

Factor 6 obtained significant loadings from six items (Cronbach's alpha $=0.919)$ : Talk with an acquaintance (0.862); Talk in a large meeting of friends (0.845); Talk with a friend (0.824); Talk in a large meeting of acquaintances (0.822); Talk in a small group of acquaintances (0.847); Talk in a small group of friends (0.844). This factor is labelled Anxiety talk with friends and acquaintances.

Factor 7 obtained significant loadings from four items (Cronbach' alpha $=0.822$ ): Speak in public to a group of strangers (0.772); Talk in a small group of strangers (0.859); 
Talk with a stranger (0.727); Talk in a large meeting of strangers (0.860). This factor is labelled Anxiety public speaking and talk with strangers.

Factor 8 obtained significant loadings from two items (Cronbach's alpha $=0.755$ ): Speak in public to a group of friends (0.896); Speak in public to a group of acquaintances (0.896). This factor is labelled Anxiety public speaking with friends and acquaintances.

Factor 9 obtained significant loadings from six items (Cronbach's alpha $=0.824$ ): I make a point of trying to understand all the English I see and hear (0.651); I keep up to date with English by working on it almost every day (0.741); I really work hard to learn English (0.794); I really try to learn English (0.806); I often think about the words and ideas which I learn about in my English course (0.776); After I graduate from college, I will continue to study English and try to improve (0.563). This factor is labelled Motivational Intensity.

Factor 10 obtained significant loadings from four items (Cronbach's alpha $=0.917$ ): Learning English is really great (0.903); I really enjoy learning English (0.922); I plan to learn as much English as possible (0.793); I love learning English (0.938). This factor is labelled Attitude to Learning English.

Factor 11 obtained significant loadings from five items (Cronbach's alpha $=0.814$ ): I have a strong desire to know all aspects of English (0.783); If it were up to me, I would spend all of my time learning English (0.757); I want to learn English so well that it will become natural to me (0.808); I would like to learn as much English as possible (0.827); I wish I were fluent in English (0.802). This factor is labelled Desire to Learn English.

The analysis of the factors obtained indicates a significant difference with respect to previous studies in the literature. Thus, the original factor willingness to communicate is retained, but subdivided into three factors: willingness to communicate/talk with friends and acquaintances; willingness to communicate/talk in dyads with a stranger, and willingness to communicate public speaking and talk with strangers.

Regarding self-perceived communication competence, the original factor in the literature is subdivided into two in the present study: Self-perceived communication competence public speaking and talk with friends and acquaintances, and Self-perceived communication competence public speaking and talk with strangers.

Finally, anxiety is also subdivided in our factor analysis into three factors: Anxiety talking with friends and acquaintances; Anxiety public speaking and talking with strangers; Anxiety public speaking with friends and acquaintances.

We find that the initial dimensions, as they appear in the literature, are recognized by individuals but suffer some modifications in our context. That is, our factor analysis reveals that the participants distinguish among receivers, namely, friends, acquaintances and strangers, and among different communication situations, that is, talking in dyads, talking in meetings, talking in groups, and public speaking. They make such distinctions when referring to their choice of whether to communicate in English or not, when reflecting on what their 
self-perceived communicative competence is, and when expressing how anxious they feel in a communicative situation in English.

Our participants clearly distinguish between informal dyads and group contexts with friends and acquaintances and formal contexts with strangers, which seems to indicate that they feel more competent and at ease in the latter than in the former.

In this respect, our study seems to agree with the results of Zarrinabadi (2012), who investigates Iranian culture values related to self-perceived communication competence. Results indicate that participants feel more competent communicating in dyads and group context and with friend and acquaintance receivers, while less competent when talking with strangers or in public and meetings.

\section{RESULTS OF THE EMPIRICAL STUDY}

Regression analysis is the instrument used to test the hypotheses formulated.

Hypothesis 1: The greater the students' level of motivation the greater their willingness to communicate.

Significant relationships are found between the three factors that refer to willingness to communicate and the three elements used to measure motivation, confirming Hypothesis 1 (see Table 2 below). Thus, there is a significant relationship between the factor Willingness to communicate/talk with friends and acquaintances and the three elements used to measure motivation: Attitude to learning English with $15.3 \%$ of variance; Motivational Intensity with $10.9 \%$ of variance; and Desire to learn English with $12.6 \%$ of variance. The level of significance is in every case $\mathrm{p}<0.001$.

There is also a significant relationship between the factor Willingness to communicate public speaking and talk with strangers and the three elements used to measure motivation: Attitude to learning English with 10\% of variance; Motivational Intensity with $10.3 \%$ of variance; and Desire to learn English with $8.1 \%$ of variance. The level of significance is in every case $\mathrm{p}<0.001$.

Finally, there is a significant relationship between the factor Willingness to communicate/talk in dyads with a stranger and the three elements used to measure motivation: Attitude towards learning English with $12.6 \%$ of variance; Motivational Intensity with $8.5 \%$ of variance; and Desire to learn English with $11.4 \%$ of variance. The level of significance is in every case $\mathrm{p}<0.001$. 


\begin{tabular}{|c|c|c|c|c|}
\hline VARIABLES & $\begin{array}{c}B \text { not } \\
\text { standardized }\end{array}$ & $\begin{array}{c}\text { BETA } \\
(B)\end{array}$ & $\begin{array}{c}\text { t- } \\
\text { VALUE }\end{array}$ & $\boldsymbol{P}$ \\
\hline \multicolumn{5}{|l|}{ WTC talk friends and acquaintances } \\
\hline $\begin{array}{l}\text { ATTITUDE TO LEARNING } \\
\text { ENGLISH }\end{array}$ & & 0.402 & 5.962 & 0.000 \\
\hline Constant & $\begin{array}{l}0.002 \\
0.085\end{array}$ & & & \\
\hline $\mathrm{R}^{2}$ & 0.161 & & & \\
\hline $\mathrm{R}^{2}$ adjusted & 0.153 & & & \\
\hline MOTIVATIONAL INTENSITY & & 0.344 & 4.934 & 0.000 \\
\hline Constant & $\begin{array}{l}0.002 \\
0.088\end{array}$ & & & \\
\hline $\mathrm{R}^{2}$ & 0.118 & & & \\
\hline $\mathrm{R}^{2}$ adjusted & 0.109 & & & \\
\hline DESIRE TO LEARN ENGLISH & & 0.367 & 5.351 & 0.000 \\
\hline Constant & $\begin{array}{c}-0.003 \\
0.086\end{array}$ & & & \\
\hline $\mathrm{R}^{2}$ & 0.135 & & & \\
\hline $\mathrm{R}^{2}$ adjusted & 0.126 & & & \\
\hline \multicolumn{5}{|l|}{$\begin{array}{l}\text { WTC public speaking and talk with } \\
\text { strangers }\end{array}$} \\
\hline $\begin{array}{l}\text { ATTITUDE TO LEARNING } \\
\text { ENGLISH }\end{array}$ & & 0.329 & 4.729 & 0.000 \\
\hline Constant & $\begin{array}{c}-0.008 \\
0.088\end{array}$ & & & \\
\hline $\mathrm{R}^{2}$ & 0.109 & & & \\
\hline $\mathrm{R}^{2}$ adjusted & 0.100 & & & \\
\hline MOTIVATIONAL INTENSITY & & 0.336 & 4.810 & 0.000 \\
\hline Constant & $\begin{array}{l}0.002 \\
0.088\end{array}$ & & & \\
\hline $\mathrm{R}^{2}$ & 0.113 & & & \\
\hline $\mathrm{R}^{2}$ adjusted & 0.103 & & & \\
\hline DESIRE TO LEARN ENGLISH & & 0.297 & 4.227 & 0.000 \\
\hline Constant & $\begin{array}{c}-0.013 \\
0.089\end{array}$ & & & \\
\hline $\mathrm{R}^{2}$ & 0.090 & & & \\
\hline $\mathrm{R}^{2}$ adjusted & 0.081 & & & \\
\hline \multicolumn{5}{|l|}{ WTC talk in dyads with a stranger } \\
\hline ATTITUDE TO LEARN ENGLISH & & 0.372 & 5.435 & 0.000 \\
\hline Constant & $\begin{array}{l}0.031 \\
0.086\end{array}$ & & & \\
\hline $\mathrm{R}^{2}$ & 0.135 & & & \\
\hline $\mathrm{R}^{2}$ adjusted & 0.126 & & & \\
\hline MOTIVATIONAL INTENSITY & & 0.313 & 4,431 & 0.000 \\
\hline Constant & $\begin{array}{c}-0.008 \\
0.088\end{array}$ & & & \\
\hline $\mathrm{R}^{2}$ & 0.094 & & & \\
\hline $\mathrm{R}^{2}$ adjusted & 0.085 & & & \\
\hline DESIRE TO LEARN ENGLISH & & 0.355 & 5.150 & 0.000 \\
\hline Constant & $\begin{array}{l}0.029 \\
0.087\end{array}$ & & & \\
\hline $\mathrm{R}^{2}$ & 0.123 & & & \\
\hline $\mathrm{R}^{2}$ adjusted & 0.114 & & & \\
\hline $\mathrm{N}$ & & 195 & & \\
\hline
\end{tabular}

Table 2. Regression analysis: motivation and WTC 
Regression analysis demonstrates the positive relationship between motivation as measured by three measures of motivation and WTC as subdivided into three factors. We can then conclude that the greater the students' motivation the greater their willingness to communicate. This result agrees with previous research that shows a clear link between motivation and L2 communication (MacIntyre \& Charos, 1996; MacIntyre \& Clément, 1996; Cameron, 2013; Yousef et al., 2013; Yashima, 2002, Yashima et al., 2013). Our study shows that motivated individuals tended to have greater predisposition to communicate. Motivation as measured by individuals' desire to learn English, their attitude to learn English and their motivational intensity appears as a key factor for students' willingness to establish communication in the foreign language.

Hypothesis 2: The greater the students' self-perceived communication competence the greater their willingness to communicate.

There is a significant relationship between self-perceived communication competence and willingness to communicate (see Table 3 below). Regression analysis was carried out among factors related to willingness to communicate and perceived competence that referred to similar receivers and similar communication situations.

We observe a significant relationship between the factor Willingness to communicate/talk with friends and acquaintances and the factor Self-perceived communication competence public speaking and talk with friends and acquaintances with $27.6 \%$ of variance. There is also a significant relationship between the factor Willingness to communicate public speaking and talk with strangers, and the factor Self-perceived communication competence public speaking and talk with strangers with $23.3 \%$ of variance. There is also a significant relationship between the factor Willingness to communicate/talk in dyads with a stranger and the factor Self-perceived communication competence public speaking and talk with strangers with $19.8 \%$ of variance. The level of significance is in every case $\mathrm{p}<0.001$.

Regression analysis shows the significant relationship between self-perceived communication competence and willingness to communicate, confirming Hypothesis 2. We can affirm that the greater the individual's perception of his or her competence the higher his/ her willingness to communicate in the foreign language. It seems then that the decision to communicate may be influenced by one's perceptions of competence. The result confirms previous studies: Baker and Macintyre (2000), McCroskey and McCroskey (1986), Matsuoka (2005), Cameron (2013), and Yousef et al. (2013). 


\begin{tabular}{|c|c|c|c|c|}
\hline VARIABLES & $\begin{array}{c}B \text { not } \\
\text { standardized }\end{array}$ & $\begin{array}{c}\text { BETA } \\
(B)\end{array}$ & $\begin{array}{c}\text { t- } \\
\text { VALUE }\end{array}$ & $P$ \\
\hline \multicolumn{5}{|l|}{$\begin{array}{l}\text { Dependent variable: WTC with } \\
\text { friends and acquaintances }\end{array}$} \\
\hline \begin{tabular}{llr}
\multicolumn{2}{l}{ SELF-PERCEIVED } & \\
COMMUNICATION & \\
COMPETENCE & PUBLIC \\
SPEAKING AND TALK & WITH \\
FRIENDS & & AND \\
ACQUAINTANCES & & \\
\end{tabular} & & 0.529 & 8.664 & 0.000 \\
\hline Constant & $\begin{array}{l}0.532 \\
0.061\end{array}$ & & & \\
\hline $\mathrm{R}^{2}$ & 0.280 & & & \\
\hline $\mathrm{R}^{2}$ adjusted & 0.276 & & & \\
\hline \multicolumn{5}{|l|}{$\begin{array}{l}\text { Dependent variable: WTC public } \\
\text { speaking and talk with strangers }\end{array}$} \\
\hline 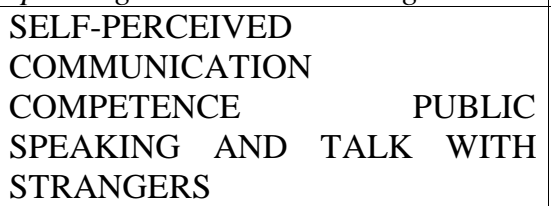 & & 0.487 & 7.742 & 0.000 \\
\hline Constant & $\begin{array}{l}0.002 \\
0.088\end{array}$ & & & \\
\hline $\mathrm{R}^{2}$ & 0.237 & & & \\
\hline $\mathrm{R}^{2}$ adjusted & 0.233 & & & \\
\hline \multicolumn{5}{|l|}{$\begin{array}{l}\text { Dependent variable: WTC talk in } \\
\text { dyads with a stranger }\end{array}$} \\
\hline $\begin{array}{l}\text { SELF-PERCEIVED } \\
\text { COMMUNICATION } \\
\text { COMPETENCE } \\
\text { SPEAKING AND TALK } \\
\text { STRANGERS }\end{array}$ & & 0.449 & 6.982 & 0.000 \\
\hline Constant & $\begin{array}{l}0.452 \\
0.065\end{array}$ & & & \\
\hline $\mathrm{R}^{2}$ & 0.202 & & & \\
\hline $\mathrm{R}^{2}$ adjusted & 0.198 & & & \\
\hline $\mathrm{N}$ & & 195 & & \\
\hline
\end{tabular}

Table 3. Regression analysis: relationship between self-perceived communicative competence and WTC

Hypothesis 3: The lower the anxiety the greater the self-perceived communication competence.

Regression analysis was carried out and a significant negative relationship was found between anxiety and self-perceived communication competence (see Table 4 below): There is a significant relationship between the factor Self-perceived communication competence public speaking and talk with friends and acquaintances and the factor Anxiety talking with friends and acquaintances with $3.1 \%$ of variance. The level of significance is $\mathrm{p}<0.05$. There is also a significant relationship between the factor Self-perceived communication competence public speaking and talk with friends and acquaintances and the factor Anxiety public speaking with friends and acquaintances with $6.9 \%$ of variance. The level of significance is $\mathrm{p}<0.001$. Finally, there is a significant relationship between the factor Self- 
perceived communication competence public speaking and talk with strangers and the factor Anxiety public speaking and talk with strangers with $10.3 \%$ of variance. The level of significance is $\mathrm{p}<0.001$.

\begin{tabular}{|c|c|c|c|c|}
\hline VARIABLES & $\begin{array}{c}B \text { not } \\
\text { standardized }\end{array}$ & $\begin{array}{c}\text { BETA } \\
(B)\end{array}$ & $\begin{array}{c}\mathrm{t}- \\
\text { VALUE }\end{array}$ & $P$ \\
\hline $\begin{array}{l}\text { Self-perceived communication } \\
\text { competence public speaking and talk } \\
\text { with friends and acquaintances }\end{array}$ & & & & \\
\hline $\begin{array}{l}\text { ANXIETY TALK WITH FRIENDS } \\
\text { AND ACQUAINTANCES }\end{array}$ & & -0.190 & -2.682 & 0.008 \\
\hline Constant & $\begin{array}{l}0.532 \\
0.061\end{array}$ & & & \\
\hline $\mathrm{R}^{2}$ & 0.036 & & & \\
\hline $\mathrm{R}^{2}$ adjusted & 0.031 & & & \\
\hline $\begin{array}{llr}\text { ANXIETY } & \text { PUBLIC } & \text { SPEAKING } \\
\text { WITH } & \text { FRIENDS } & \text { AND } \\
\text { ACQUAINTANCES } & \end{array}$ & & -0.272 & -3.921 & 0.000 \\
\hline Constant & $\begin{array}{c}-0.273 \\
0.070\end{array}$ & & & \\
\hline $\mathrm{R}^{2}$ & 0.074 & & & \\
\hline $\mathrm{R}^{2}$ adjusted & 0.069 & & & \\
\hline $\begin{array}{l}\text { Self-perceived communication } \\
\text { competence public speaking and talk } \\
\text { with strangers }\end{array}$ & & & & \\
\hline $\begin{array}{llr}\text { ANXIETY } & \text { PUBLIC } & \text { SPEAKING } \\
\text { AND TALK } & \text { WITH STRANGERS }\end{array}$ & & -0.328 & -4.824 & 0.000 \\
\hline Constant & $\begin{array}{c}-0.190 \\
0.071 \\
\end{array}$ & & & \\
\hline $\mathrm{R}^{2}$ & 0.108 & & & \\
\hline $\mathrm{R}^{2}$ adjusted & 0.103 & & & \\
\hline$N$ & \multicolumn{4}{|c|}{195} \\
\hline
\end{tabular}

Table 4. Regression analysis: relationship between anxiety and self-perceived communicative competence

We can say that the lower the anxiety greater the perceived competence. This confirms previous studies (Croucher, 2013). Those students who feel less anxiety when speaking in the foreign language tend to perceive that their own competence is higher.

The next hypothesis aims at testing the relationship between self-perceived communication competence and L2 competence. There are factors outside language competence that could also influence this relationship. One of them is gender. Considering the interest of approaching a possible influence of gender on these relationships and the paucity of studies that approach this issue we will include gender in our regression analyses.

Hypothesis 4: The greater the self-perceived communication competence the greater the level of 22 competence.

A significant relationship is found between self-perceived communication competence and L2 competence, confirming hypothesis four (see Table 5 below). There is a significant relationship between the factor Self-perceived communication competence public speaking 
and talk with friends and acquaintances and L2 competence with $22.7 \%$ of variance. The level of significance is $\mathrm{p}<0.001$. There is also a significant relationship between the factor Self-perceived communication competence public speaking and talk with strangers and L2 competence with $8.2 \%$ of variance. The level of significance is $p<0.001$.

A gender effect was found in the relationship between the factor Self-perceived communication competence public speaking and talk with friends and acquaintances and $L 2$ competence in the sense that this relationship is worse in the case of women. The level of significance is $\mathrm{p}<0.05$.

\begin{tabular}{|c|c|c|c|c|}
\hline VARIABLES & $\begin{array}{c}B \text { not } \\
\text { standardized }\end{array}$ & $\begin{array}{c}\text { BETA } \\
(B)\end{array}$ & $\begin{array}{c}\text { t- } \\
\text { VALUE }\end{array}$ & $\boldsymbol{P}$ \\
\hline \multicolumn{5}{|l|}{ Dependent variable: L2 Competence } \\
\hline PERCEIVED COMPETENCE & & \multirow[t]{4}{*}{0.474} & \multirow[t]{4}{*}{7.499} & \multirow[t]{4}{*}{0.000} \\
\hline PUBLIC SPEAKING AND TALK & & & & \\
\hline $\begin{array}{lll}\text { WITH } & \text { FRIENDS } & \text { AND }\end{array}$ & & & & \\
\hline ACQUAINTANCES & & & & \\
\hline GENDER & & -0.138 & -2.185 & 0.030 \\
\hline Constant & $\begin{array}{c}121.551 \\
1.683\end{array}$ & & & \\
\hline $\mathrm{R}^{2}$ & 0.235 & & & \\
\hline $\mathrm{R}^{2}$ adjusted & 0.227 & & & \\
\hline \multicolumn{5}{|l|}{ Dependent variable: L2 Competence } \\
\hline \multirow{2}{*}{$\begin{array}{l}\text { PERCEIVED COMPETENCE } \\
\text { PUBLIC SPEAKING AND TALK } \\
\text { WITH STRANGERS }\end{array}$} & & \multirow[t]{2}{*}{0.284} & \multirow[t]{2}{*}{4.123} & \multirow[t]{2}{*}{0.000} \\
\hline & & & & \\
\hline Constant & $\begin{array}{c}121.088 \\
1.686\end{array}$ & & & \\
\hline $\mathrm{R}^{2}$ & 0.092 & & & \\
\hline $\mathrm{R}^{2}$ adjusted & 0.082 & & & \\
\hline $\mathrm{N}$ & & 195 & & \\
\hline
\end{tabular}

Table 5. Regression analysis: relationship between self-perceived communicative competence and L2 competence

We can then conclude that the greater the individuals' self-perceived communication competence the higher their proficiency. Those students who have a higher perception of their competence in English tend to have higher proficiency in the language as well. This confirms previous results in the literature (Yashima, 2002; Yashima et al., 2004). Results also show a slight gender effect in the sense that with similar levels of perceived competence, L2 competence is influenced by gender and is slightly lower in the case of women.

\section{DISCUSSION}

The importance of communication in L2 teaching and learning and the lack of studies that approach students' attitudes to communication in a Spanish higher education context led us to carry out an empirical study that focusses on the relationships among the variables believed to affect Spanish learners' willingness to communicate in English. 
We carried out a factor analysis that reveals that the original dimensions present in the literature referring to willingness to communicate, self-perceived communication competence, and anxiety, remain in our study but with variations. These variations seem to show that participants feel more competent and more comfortable when communicating in dyads and group contexts and with friend and acquaintance receivers, than when talking with strangers or in public and meetings. This conclusion is obviously only tentative and will have to be tested in future research studies.

All of the hypotheses formulated in the present study have been proven, confirming previous research studies in our context. We found that the level of motivation influences willingness to communicate so that the more motivated the students the more they were willing to communicate.

Self-perceived communication competence was a significant influence for willing to communicate and we found that a higher perception of communicative competence led to a higher level of willingness to communicate.

The study also confirmed the close relation shown by the literature between anxiety and self-perceived communication competence so that the lower the anxiety the higher the perceived competence.

Finally, results show a significant relationship between self-perceived communication competence and L2 competence so that we can say that the greater the students' selfperceived communication competence the higher their L2 competence. We can then affirm that our group of students have adequate knowledge of their actual proficiency in English.

An interesting finding points to some gender difference in the relationship between self-perceived communication competence and L2 competence. We found that with similar levels of self-perceived competence in both sexes, L2 competence is influenced by gender and tends to be lower in women. One possible explanation could be the less instrumentalist view of languages women seem to have. Whereas men tend to study languages with a specific objective, mainly professional in mind, for women learning a foreign language may involve a wider variety of reasons, not only professional but also related to pleasure or learning for the sake of it. As we saw above, in Baker and MacIntyre (2000) the male immersion students showed the highest job-related orientation, whereas the female nonimmersion students showed the highest knowledge and personal-achievement orientations which these authors attribute to females' social orientation. Similarly, Mori and Gobel (2005) found that female students scored significantly higher in integrative (cultural and interpersonal) reasons for studying English than male students.

This less instrumentalist perspective, the fact that women in general tend to study English with a more general aim than men, could explain why, although women may have a high self-perception of their competence regarding public speaking and talk with friends and acquaintances, when it comes to real competence, this appears to be slightly lower. This is in line with research in educational psychology by Eccles (1994), whose expectancy x value 
model of achievement motivation developed to address gender differences in educational or occupational choices, links achievement outcomes to self-perceptions and self-concept.

Moreover, it is likely that men may be familiar with a wider range of topics than women are, also because of their more instrumentalist view of learning languages, which could also explain their higher L2 competence. The gender effect is small and refers to a specific communication situation, but it is clearly an interesting finding and more studies are needed that approach this issue and try to confirm this result with different groups of men and women by including other factors in the study (topics of interest, reasons to learn English of both sexes, etc.).

\section{CONCLUSIONS}

As already mentioned, communicative competence in the target language is the final objective of language learning. MacIntyre et al. (1998) argued that the ultimate goal of the second or foreign language learning should be to "engender in language students the willingness to seek out communication opportunities and the willingness actually to communicate in them" (p. 547). Studies like the present one may help language teachers improve their communicative language teaching methods and curriculum design, to find a better way to develop language learners' communication willingness in the target language, and increase their engagement in communication.

\section{REFERENCES}

Baker, S. C. \& MacIntyre, P. D. (2000). The role of gender and immersion in communication and second language orientations. Language Learning, 50(2), 311-341.

Cameron, D. (2013). Willingness to communicate in English as a second language as a stable trait or context-influenced variable: Case studies of Iranian migrants to New Zealand. Australian Review of Applied Linguistics, 36(2), 177-196.

Cao, Y. \& Philp, J. (2006). Interactional context and willingness to communicate: A comparison of behaviour in whole class, group and dyadic interaction. System, 34, 480-493.

Clément, R., Dörnyei, Z. \& Noels, K. (1994). Motivation, self-confidence and group cohesion in the foreign language classroom. Language Learning, 33, 273-291.

Croucher, S. M. (2013). Communication apprehension, self-perceived communication competence, and willingness to communicate: A French analysis. Journal of International and Intercultural Communication, 6(4). 298-316.

Dörnyei, Z. (2007). Research Methods in Applied Linguistics: Quantitative, Qualitative and Mixed Methodologies. Oxford: Oxford University Press.

Eccles, J. S. (1994). Understanding women's educational and occupational choices: Applying the Eccles et al. Model of Achievement-Related Choices. Psychology of Women Quarterly, 18, 585-610.

Gardner, R. C. (1985). Social Psychology and Second Language Learning: The role of Attitudes and Motivation. London: Arnold.

Gardner, R. C. (2001). Integrative Motivation: Past, Present and Future. Paper presented as Distinguished Lecture Series. Temple University Japan, Tokyo. 
Gardner, R. C. \& Lambert, W. C. (1972). Attitudes and Motivation in Second Language Learning. Rowley, MA: Newbury House.

Gardner, R. C. \& MacIntyre, P. D. (1993). On the measurement of affective variables in second language learning. Language Learning, 43(2), 157-194.

Gardner, R. C., Tremblay, P. A. \& Masgoret, A. (1997). Towards a full model of second language learning: An empirical investigation. Modern Language Journal, 81, 344-362.

Kang, S.-J. (2005). Dynamic emergence of situational willingness to communicate in a second language. System, 33, 277-292.

MacIntyre, P. D. (1994). Variables underlying willingness to communicate: A causal analysis. Communication Research Reports, 11, 135-142.

MacIntyre, P. D. \& Charos, C. (1996). Personality, attitudes, and affect as predictors of second language communication. Journal of Language and Social Psychology, 15, 3-26.

MacIntyre, P. D. \& Clément, R. (1996). A Model of Willingness to Communicate in a Second Language: The Concept, its Antecedents and Implications. Paper presented at the World Congress of Applied Linguistics (AILA). Jyväskylä, Finland, August, 4-9.

MacIntyre, P. D. \& Legatto, J. J. (2011). A dynamic system approach to willingness to communicate: Developing an idiodynamic method to capture rapidly changing affect. Applied Linguistics, 32(2), 149-171.

MacIntyre, P. D., Clément, R., Dörney, Z. \& Noels, K. (1998). Conceptualizing willingness to communicate in a L2: A situational model of L2 confidence and affiliation. The Modern Language Journal, 82(IV), 545-562.

Matsuoka, R. (2005). Japanese Students' Willingness to Communicate in English. Unpublished doctoral dissertation, Temple University, MI.

McCroskey, J.C. (1992). Reliability and validity of the willingness to communicate scale. Communication Quarterly, 40, 16-25.

McCroskey, J. C. (1997). Willingness to communicate, communication apprehension, and selfperceived communication competence: Conceptualizations and perspectives. In J. A. Daly, J. C. McCroskey, J. Ayres, T. Hopf \& D. M. Ayres (Eds.), Avoiding Communication: Shyness, Reticence, and Communication Apprehension (pp. 75-108). Cresskill, NJ: Hampton Press Inc.

McCroskey, J. C. \& Baer, J. E. (1985). Willingness to communicate: The construct and its measurement. Paper presented at the Annual Convention of the International Communication Association. Chicago. November, 1985.

McCroskey, J. C. \& McCroskey, L. L. (1986). Correlates of willingness to communicate. Paper presented at the Western Speech Communication Association Convention. Tucson, AZ. February, 1986.

McCroskey, J. C. \& McCroskey, L. L. (1988). Self-report as an approach to measuring communication competence. Communication Research Reports, 5(2), 108-113.

Mori, S. \& Gobel, P. (2005). Motivation and gender in the Japanese EFL classroom. System, 34(2), 194-210.

Peng, J. (2013). The challenge of measuring willingness to communicate in EFL contexts. AsiaPacific Education Researcher, 22(3), 281-290.

Yashima, T. (2002). Willingness to communicate in a second language: The Japanese EFL context. The Modern language Journal, 86(I), 54-66.

Yashima, T., Zenuk-Nishide, L. \& Shimizu, K. (2004). The influence of attitudes and affect on willingness to communicate and second language communication. Language Learning, 54(1), 119-152.

Yousef, R., Jamil, H. \& Razak, N. (2013). Willingness to communicate in English: A study of Malaysian pre-service English teachers. English Language Teaching, 6(9), 205-216.

Zarrinabadi, N. (2012). Self-perceived communication competence in Iranian culture. Communication Research Reports, 29(4), 292-298. 